\title{
Grass response to seasonal burns in experimental plantings
}

\author{
HENRY F. HOWE
}

Author is professor of Biological Sciences (M/C 066), University of Illinois at Chicago, 45 W. Taylor Street, Chicago, Ill. 60607.

\begin{abstract}
A 6-year experiment examined the effects of spring and summer fires on grasses in southern Wisconsin. Synthetic communities of $C_{3}$ and $C_{4}$ grasses were seeded ( 100 seeds $~^{-2}$ species $^{-1}$ ) in 1992 and subjected to prescribed burns in May and August of 1995 and 1997, or left unburned. By 1994 all plots were virtual monocultures of the $\mathrm{C}_{3}$ reed canary grass (Phalaris arundinacea L.). By the second post-season sample in 1998 , total productivity

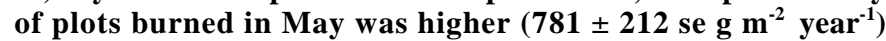
than those burned in August $\left(362 \pm 28 \mathrm{~g} \mathrm{~m}^{-2}\right.$ year $\left.^{-1}\right)$ or left unburned $\left(262 \pm 43 \mathrm{~g} \mathrm{~m}^{-2}\right.$ year $\left.^{-1}\right)$ due to the incursions of either the $\mathrm{C}_{4}$ grasses big bluestem (Andropogon gerardii Vitman), switichgrass (Panicum virgatum $\mathrm{L}$ ), or both. These large late-season grasses are much more productive per area covered than $\boldsymbol{P}$. arundinacea or the other two $\mathrm{C}_{3}$ grasses present, Elymus virgini cus $\mathbf{L}$. and Poa pratensis $\mathrm{L}$. Even at this early stage of succession, $\mathrm{C}_{4}$ production in plots burned in May was 5 to 6 times that in the other 2 treatments. August burns produced a mix of $C_{3}$ and $C_{4}$ grasses but did not strongly favor the pre-treatment $\mathrm{C}_{3}$ dominant $P$. arundinacea. Unburned plots most resembled those burned in August in species composition, but differed in having 4 times the accumulated litter, perhaps foretelling divergence in $C_{3}$ and $C_{4}$ composition as succession proceeds.
\end{abstract}

Key Words: $\mathrm{C}_{3}$ grass, $\mathrm{C}_{4}$ grass, fire season, ecological restoration, tallgrass prairie

Fire slows or precludes woody succession into tallgrass vegetation in the central United States (e.g. Saur 1950, Curtis 1959, Daubenmire 1968, Risser et al. 1981, Collins and Wallace 1990), justifying the well-established practice of using prescribed fire to maintain tallgrass prairie and related communities (e.g. Hulbert 1973, 1986, Rock 1981, McCain 1986). Prescribed fire maintains tallgrass prairie structure, productivity, and diversity as compared to unburned remnants (Leach and Givnish 1996), but the seasonal effects of fire on structure of herbaceous plant communities are less understood (Bragg 1982, Higgins 1984, Towne and Owensby 1984). For instance, spring fires may favor dominance by lateremerging species, such as large $\mathrm{C}_{4}$ grasses, while fires during the middle of the growing season could suppress such "warm-sea-

I am grateful to R. Dustin for field preparation and J. and L. Hansen, D. and K. Minsky, and G. and L. Nessler for help with other fieldwork. N. Cordeiro, R. Harari-Kremer, C. Martinez-Garza, M. Pacheco, and 3 reviewers offered helpful comments on the manuscript. C. Martinez-Garza translated the abstract into Spanish. Design and establishment of the plots were supported by the United States Department of Agriculture (88-38300-3622), later stages of the project by the National Science Foundation (DEB 94-24546, DEB 98-15289).

Manuscript accepted 16 Oct. 1999.
Resumen

Un experimento de 6 anos examino los efectos del fuego en pastos durante la primavera y verano en el sur de Wisconsin. Comunidades sintéticas de pastos $C_{3}$ y $C_{4}$ fueron creadas al sur de Wisconsin en 1992 y se les aplicó fuegos prescritos en Mayo y Agosto de 1995 y 1997, o fueron dejados sin quemar. Para 1994 todos las parcelas fueron monocultivos del pasto $\mathrm{C}_{3}$ Phalaris arundinacea $\mathrm{L}$. En la segunda muestra despues de la quema de 1998, la productividad total de las parcelas quemadas en Mayo

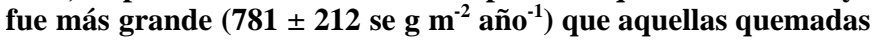
en Agosto (362 $\pm 28{\mathrm{se} \mathrm{g} \mathrm{m}^{-2} \text { año }}^{-1}$ ) o las que no fueron quemadas

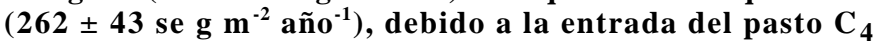
Andropogon gerardii Vitman, Panicum virgatum L., o los dos. Estos dos grandes pastos tardíos son mucho más productivos por área que $P$. arundinacea o los otros dos pastos $C_{3}$ presentes, Elymus virginicus $\mathbf{L}$. y Poa pratensis $\mathrm{L}$. Incluso para este joven estado de sucesión, la producción de los pastos $C_{4}$ en parcelas quemadas en Mayo es de 5 a 6 veces más alta que en los otros 2 tratamientos. La quema de Agosto produjo una mezcla de pastos $\mathrm{C}_{3} \mathrm{y} \mathrm{C}_{4}$ pero no favorecio fuertemente la dominancia de $P$. arun dinacea. Las parcelas que no fueron quemadas son parecidas a aquellas que fueron quemadas en Agosto en terminos de la identidad de las especies, pero difieren en que las parcelas no quemadas tienen 4 veces más hojarasca acumulada, quizas pronosticando divergencias en la composición de $C_{3}$ y $C_{4}$ a estados más avanzados de la sucesión.

son" species in favor of dominant earlier-emerging $\mathrm{C}_{3}$ grasses (Higgins 1984, Hulbert 1988, Howe 1994a, 1994b, 1995). Any fire may maintain grassland structure by precluding woody succession, but the season of fire may largely determine which herbaceous communities persist.

This paper reports on the effects of fire season on synthetic grass communities established on plowed land in 1992 in southwestern Wisconsin. The preliminary objective after 2 alternateyear burn cycles is to test the hypotheses: (1) summer fire favors early-season $\mathrm{C}_{3}$ grasses, and (2) spring fire favors late-season $\mathrm{C}_{4}$ grasses. Because $\mathrm{C}_{3}$ grasses are less productive than $\mathrm{C}_{4}$ grasses, one expects lower productivity after summer than spring fires. After 2 additional burn cycles these questions will be revisited for both aggregate and species-specific variables.

\section{Methods}

Three early cool-season $\left(\mathrm{C}_{3}\right)$ and 3 late warm-season $\left(\mathrm{C}_{4}\right)$ grass species were sown at equal densities of 100 seeds $\mathrm{m}^{-2}$ species $^{-1}$ on 14 June 1992 in eighteen, $7 \times 7$ m plots in a $3 \times 6$ grid in a wet- 
mesic sandy loam near Viola, Vernon County, Wisc. with procedures adapted from Rock (1981). In 1991 pre-existing pasture vegetation of Eurasian grasses was sprayed with contact herbicide (glyphosate) on 18 May, plowed and disced on 20 June, sprayed again on 22 June to kill surviving quackgrass (Agropyron repens L), and disced on 28 July 1991 and 6 June 1992.

Seeds mixed with damp sand were broadcast on 14 June 1992 in each $7 \times 7$ m plot from 1 of 18 individually measured and weighed bags of $\mathrm{C}_{3}$ wheatgrass (Agropyron trachycaulum [Link] Malte), Virginia rye (Elymus virginicus L.), reed canary-grass (Phalaris arundinacea L.), and $\mathrm{C}_{4}$ grasses big bluestem (Andropogon gerardii) Vitman, switchgrass (Panicum virgatum L.) and prairie dropseed (Sporobolus heterolepis [Gray] Gray). Plots were raked and rolled. Cover of annual oats (Avena sativa L.) at 100-150 seeds $\mathrm{m}^{-2}$ suppressed invasive weeds while perennial plantings established the first growing season (see Rock 1981). Future fire lanes $1.5 \mathrm{~m}$ wide were broadcast-seeded, raked and rolled with the same seed mix between the plots. A uniform burn on 24 April 1994 reduced weeds and litter and permitted establishment of $\mathrm{C}_{4}$ grasses. The growing season for $\mathrm{C}_{3}$ grasses in this valley is April to October when not heavily shaded by other herbaceous or woody species. The growing season for $\mathrm{C}_{4}$ grasses is May to late September.

Seasonal fire treatments commenced in 1995 and were repeated in 1997 . On 18 May 1995, 6 plots were burned, 1 randomly picked from each of 6 north-south rows; on 12 August 1995, 6 similarly selected plots were burned. The third plot in each north-south row remained unburned. Plots burned in May 1995 were again burned on 4 May 1997, those burned in August 1995 were again burned on 1 August 1997. Fuel load was estimated using dry mass of clippings of live foliage of the year and dead litter in 2 randomly selected $25 \times 25 \mathrm{~cm}$ samples from each plot to be burned 1-4 days before each fire; in August 1997 clippings were repeated after burns. Ring fires were set on the first nearly windless late afternoon (after $4 \mathrm{pm}$ ) of May or August on plots that had been spared rain $(\geq 1 \mathrm{~cm})$ for 2 days. In 1995 a representative flame length was recorded $>1 \mathrm{~m}$ from the edge for each plot; in 1997 flame lengths at random locations were measured 4-6 times at 20 second intervals in each plot, and the mean values for the plots were analyzed. In 1997 the time required to engulf each 7 x $7 \mathrm{~m}$ plot was recorded after the perime- ter was ignited with a drip torch, which took about 1 minute. The proportion of area in which herbaceous shoots were killed was recorded both years. A shorthand calculation of fire intensity $\mathrm{I}=$ $259.83 \mathrm{~L}^{2.174}$ (Johnson 1992), where L is flame length in $\mathrm{m}$ allows comparison of potential for fire effects independent of measured plant responses.

Response variables measured were estimates of above-ground primary production, litter, and canopy cover taken $\geq 1 \mathrm{~m}$ from the edge of each plot. Dry mass of live vegetation was estimated with clippings from 5 randomly located $25 \times 25 \mathrm{~cm}$ samples (exclusive of permanent cover plots, below) in late August or early September 1993, 1996, and 1998. Shoots of the year were dried to constant mass; in 1996 and 1998 dry litter was also evaluated, and in 1998 dry shoots of the year were separated by species. Values reported are converted to $\mathrm{g} \mathrm{m}^{-2}$ (g/sample $\left.\mathrm{x} 16\right)$. Canopy cover was determined in 5 randomly-located permanent $\mathrm{m}^{2}$ plotlets. A map was drawn to scale of relative cover of all vegetation occupying $\geq 10 \times 10 \mathrm{~cm}$ of continuous space within a plotlet; area per species was determined with a Lasico digital planimeter (Howe 1994b).

In this experiment burns are carried out in May and August of the same year, and this sequence is repeated in alternate years. Responses are evaluated in nonburn years. This means that spring burns are evaluated about 1.75 growing seasons after the burn, and August burns about 1.25 growing seasons after the burn, assuming either that $\mathrm{C}_{3}$ or $\mathrm{C}_{4}$ grasses, or both, grow from April through September. Because differences in productivity are due to inherent differences in productivity of species responding to the month of burn, the one half season difference in growth does not appear to be important; $\mathrm{C}_{3}$ species present are always a fraction of the biomass $\mathrm{m}^{-2}$ of the $\mathrm{C}_{4}$ species used in these plantings. An alternative, to burn in August of 1 year, in May of the next, and to evaluate productivity in autumn of the second year, would leave a similar but reversed one half season disparity in growing time (for August burns, evaluation after 1.25 growing seasons, for May burns after 0.75 season). The additional burden for interpretation of different year burns would be confounded by differences in growing times with unshared winter effects and unshared growing season effects in the critical early weeks of recovery from burns. Either burn regime could have consequences for conspecific comparisons, but neither would appear to make much difference in a system where differences in productivity are due to interspecific responses, not subtle variations in intraspecific recovery.

Dicot weeds were sprayed with 2-4 dichlorophenoloxyacetic acid in May and June after 1993; in July and August they were clipped (large roots) or pulled (small roots) on sight. Invasive graminoids were not weeded (the Avena cover crop disappeared by 1993).

The experiment was set up in a split-plot design, with burn treatments randomly assigned within each of 6 rows of 3 plots. Because no row effect materialized, data are analysed as a straightforward multivariate anova to make maximum use of degrees of freedom (Wilkinson 1993).

\section{Results}

Succession. The plots changed dramatically between the 1992 planting and 1998 census. In 1992, most canopy cover was of graminoid weeds $(41 \pm 5 \%)$ and the Avena cover crop $(27 \pm 4 \%)$. All 6 experimental grasses appeared by 1993 , but $S$. het erolepis was only present in trace numbers before disappearing, while A. trachy caulum was common in 1992 (canopy cover of $24 \pm 3 \%$ ) but disappeared by 1994. P. arundinacea appeared in 1992 (3 $\pm 1 \%$ ), was a virtual monoculture by 1994 $(97 \pm 1 \%)$, and diminished in $1996(82 \pm$ $4 \%)$ and $1998(41 \pm 7 \%)$. The large $\mathrm{C}_{3}$ species E. virginicus became abundant in $1996(8 \pm 3 \%)$ and $1998(6 \pm 2 \%)$. Large $\mathrm{C}_{4}$ species $A$. gerardii and $P$. virgatum first gained prominence in 1996 (3 \pm 2 and $5 \pm 2 \%)$ and appeared to increase overall in $1998(10 \pm 4$ and $13 \pm 5 \%$, respectively). By 1996, E. virginicus and the smaller volunteer $P$. pratensis partially displaced $P$. arundinacea in unburned and summerburn plots. Andropogon gerardii and $P$. virgatum now occur in all plots, have virtually eliminated $P$. arundinacea from 2 spring-burn plots, and are gaining ground in the other spring-burn plots. Twentyfour dicot and 4 graminoid weeds dominated the plots during the first growing season ("other" in Fig. 1). Dicots swamp aster (Aster simplex Willd.) and tall goldenrod (Solidago altissima L.) required persistent control in all plots, and fleabane (Erigeron spp.) and chickweed (Stellaria media [L.] Vill.) required control in unburned and summer-burn plots. Of the graminoid weeds present, only the $\mathrm{C}_{3}$ grass Poa pratensis L. became at all common, and then primarily in summer-burn plots. 

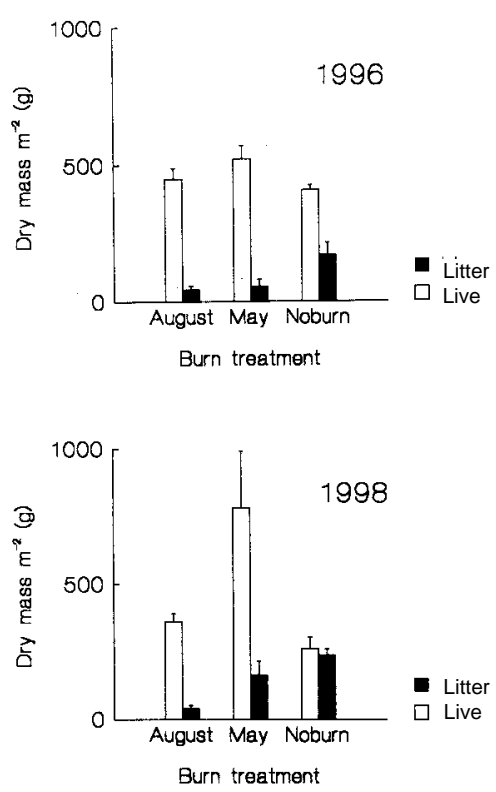

Fig. 1. Above-ground production and litter per square meter in 1996 after 1995 burns, and in 1998 after 1997 burns (mean \pm se g).

Fuel loads. May and August burns in 1995 removed all litter and left negligible standing-dead vegetation; a low-intensity burn in August 1997 left nearly 30\% standing dead $\left(132 \pm 39 \mathrm{~g} \mathrm{~m}^{-2}\right)$. May burns occurred when green vegetation averaged $25-40 \mathrm{~cm}$ tall, and accounted for much less of the above-ground biomass than August burns. By August green vegetation averaged $100-120 \mathrm{~cm}$ tall and accounted for most biomass above ground (Table 1), enough to reduce fire intensity when significant rain $(\geq 1 \mathrm{~cm})$ fell within 3 days of the burns (e.g. 1997).

Fire behavior. Fire behavior differed among treatments and years (Table 1). Flame length ranged from 0.25 to $0.78 \mathrm{~m}$ with a mean of $0.60 \pm 0.10 \mathrm{~m}$ (mean \pm $1 \mathrm{se}$ ) in the May 1995 burns, but 1.25 to $1.50 \mathrm{~m}$ with a mean of $1.29 \pm 0.04 \mathrm{~m}$ in August. Two years later the May 1997 burns ranged from 0.75 to $1.62 \mathrm{~m}$ with a mean of $1.19 \pm 0.15 \mathrm{~m}$, while the August burns resembled the May 1995 burns with flame lengths of 0.44 to $0.85 \mathrm{~m}$, averaging $0.67 \pm 0.6 \mathrm{~m}$. In 1997 plots burned in May were engulfed in $2.7 \pm 0.3$ minutes, while the less intense August fires took $4.2 \pm 0.4$ minutes. Fire intensities were greater in August than May fires in 1995, but higher in May than August in 1997. The policy of burning on windless late afternoons undoubtedly reduced fire intensities over those that might have been recorded earlier on same days.

Above-ground productivity. Aboveground productivity in August 1993, then $P$. arundinacea L. and some $E$. virginicus, averaged $495 \pm 66 \mathrm{~g} \mathrm{~m}^{-2}$, with no differences among plots later assigned to different burn treatments (Tukey tests, $\mathrm{P}>0.5$ ). Following the 1995 burns, 1996 samples were not different in overall productivity by burn treatment $\left(\mathrm{F}_{2,15}=2.475, \mathrm{P}=0.1\right)$, although unburned treatments accumulated more litter $\left(\mathrm{F}_{2,15}=5.744, \mathrm{P}<0.025\right.$; Fig. 1 top). Wilks' lambda $\left(0.447, \mathrm{~F}_{4,28}=\right.$ $3.466, \mathrm{P}=0.02)$ and the multivariate exact probability theta $(0.498 \mathrm{~S}=2, \mathrm{M}=-.5, \mathrm{~N}=$ $6.0, \mathrm{P}=0.027$; Wilkinson 1993) indicate a significant combined response of productivity and litter to burn season. A year after the second burn (Fig. 1 bottom), productivity and litter deposition differed among burn treatments (univariate tests: $\mathrm{F}_{2,15}=4.797$ and $9.953, \mathrm{P}<0.025$ and $\mathrm{P}=$ 0.002 , respectively). Again there is a combined multivariate response of both annual productivity and litter with treatment (Wilks' lambda $0.159, \mathrm{~F}_{4,28}=10.582, \mathrm{P}<$ 0.001 and theta $=0.765 \mathrm{~S}=2 \mathrm{~m}=-.05, \mathrm{~N}=$ $6.0, \mathrm{P}<0.001)$.

Table 1. Fuel conditions, fire intensities, and immediate effects on above-ground vegetation. Fuel and litter are reported as means ( \pm se) from two, $25 \times 25 \mathrm{~cm}$ samples from each plot the day before burns in May or August (transformed to green shoots or litter $\mathrm{m}^{-2}$ ); fire intensities (mean \pm se) are derived from 4-6 flame lengths from each plot. ${ }^{1,2,3}$ Percent kill indicates the area $\left(\mathrm{m}^{2}\right.$ of total $\mathrm{m}^{2}$ per plot $\mathrm{x} 100$ ) in each plot for which $100 \%$ of the above-ground vegetation was killed. ${ }^{4}$

\begin{tabular}{lcccccc}
\hline \hline & & & Vegetation & & \multicolumn{2}{c}{ Fire } \\
\cline { 5 - 6 } Year & Plots & $\begin{array}{c}\text { Green } \\
\text { mass }\end{array}$ & $\begin{array}{c}\text { Litter } \\
\text { mass }\end{array}$ & $\begin{array}{c}\text { Percent } \\
\text { green }\end{array}$ & Intensity & Percent kill \\
\hline \multirow{2nnnyyy}{*}{ 1995 May } & 6 & $72 \pm 4^{\mathrm{a}}$ & $296 \pm 29^{\mathrm{a}}$ & $20 \pm 2^{\mathrm{a}}$ & $98 \pm 25^{\mathrm{a}}$ & $(\%)$ \\
August & 6 & $536 \pm 106^{\mathrm{b}}$ & $198 \pm 19^{\mathrm{b}}$ & $71 \pm 4^{\mathrm{b}}$ & $456 \pm 34^{\mathrm{b}}$ & 97 \\
1997 May & 6 & $19 \pm 3^{\mathrm{a}}$ & $299 \pm 31^{\mathrm{a}}$ & $6 \pm 1^{\mathrm{b}}$ & $421 \pm 107^{\mathrm{b}}$ & 100 \\
August & 6 & $310 \pm 39^{\mathrm{c}}$ & $234 \pm 19^{\mathrm{b}}$ & $56 \pm 3^{\mathrm{d}}$ & $116 \pm 22^{\mathrm{a}}$ & 100 \\
\hline
\end{tabular}

${ }^{1}$ Intensity is $\mathrm{I}=259.83 \mathrm{~L}^{2.174}$, where $\mathrm{L}$ is flame length in $\mathrm{m}$ (Johnson 1992).

${ }^{2}$ Means accompanied by different superscripts differ by Tukey tests at least at $\mathrm{P}<0.05$.

${ }^{3}$ Fuel conditions were not assessed for unburned plots.

${ }^{4}$ Grasses regularly resprouted from live underground buds.

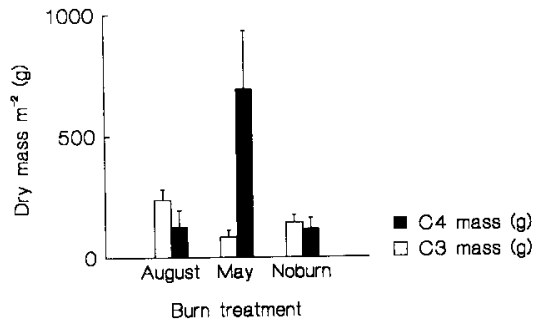

Fig. 2. Annual production of $\mathrm{C}_{3}$ and $\mathrm{C}_{4}$ grasses per square meter in 1998 after 1997 burns (mean \pm se g).

The $\mathrm{C}_{4}$ grasses were more productive than $\mathrm{C}_{3}$ grasses. Pooling all treatments, in $1998 C_{4}$ grasses $A$. gerardii and $P$. virga tum accounted for $10 \%$ and $14 \%$ of the area covered, but $22 \%$ and $26 \%$ of the biomass, respectively. The $\mathrm{C}_{3}$ grasses $E$. vir ginicus, $P$. arundinacea, and $P$. pratensis accounted for $6 \%, 41 \%$ and $21 \%$ of the area covered, but $3 \%, 30 \%$, and $19 \%$ of the biomass, respectively. Over all treatments, $\mathrm{C}_{4}$ grasses accounted for $23 \%$ of the cover and $48 \%$ of the biomass, while $\mathrm{C}_{3}$ grasses accounted for $71 \%$ of the cover and $52 \%$ of the biomass.

$C_{3}$ and $C_{4}$ grasses. By 1998 burn treatments affected biomasses of $\mathrm{C}_{3}$ and $\mathrm{C}_{4}$ grasses (Fig. 2; $\mathrm{F}_{2,15}=4.962$ and 5.199, respectively, $\mathrm{P}<0.025)$, and the combined response of both variables (Wilks' lambda $0.414, \mathrm{~F}_{4,28}=3.873, \mathrm{P}<0.025 ;$ theta $=$ $0.428 \mathrm{~S}=2 \mathrm{~m}=-.05, \mathrm{~N}=6.0, \mathrm{P}=0.063$ ). Tukey tests show less green biomass of $\mathrm{C}_{3}$ grasses the season following May than August burns ( $\mathrm{P}<0.02)$, and more biomass of $C_{4}$ grasses 1.75 growing seasons after May than 1.25 growing seasons after August burns or in unburned plots ( $\mathrm{P}<$ $0.05)$.

At this stage of succession, high variance within and between treatments preclude significant effects of burn times for individual species. In some May-burn plots, for instance, $P$. virgatum is present in samples but $A$. gerardii is absent, while in other plots the opposite is true. One significant effect of treatment is the greater biomass of the invasive $\mathrm{C}_{3}$ grass $P$. pratensis in plots burned the previous year in August $\left(84.8 \pm 20.8 \mathrm{~g} \mathrm{~m}^{-2}\right)$ than in May $\left(24.0 \pm 9.6 \mathrm{~g} \mathrm{~m}^{-2}\right.$; Tukey test, $\left.\mathrm{P}<0.05\right)$.

\section{Discussion}

This study improves understanding of seasonal fire effects on tallgrass vegetation planted in a wet-mesic field. As expected, spring fires strongly promote overall productivity through enhanced establishment and growth of $\mathrm{C}_{4}$ at the expense of $\mathrm{C}_{3}$ 
grasses (e.g. Hulbert 1988, Howe 1995). However, summer fires do not increase the representation of dominant $\mathrm{C}_{3}$ grasses nearly as much as expected. Instead of favoring dominant $P$. arundinacea, 2 cycles of summer burns have admitted 2 additional $\mathrm{C}_{3}$ and 2 additional $\mathrm{C}_{4}$ grasses, but the individual species responses are not clearly different from unburned plots.

\section{Response to fire season}

The imposition of fire, and to some degree fire frequency, is often perceived as "the treatment" in grassland management (Howe 1994a). In this study in a wetmesic planting, fire season appears to promote very different communities out of identical seedings in as little as 6 years.

The most decisive response in the first 6 years of this experiment is the continuing replacement of a virtual monoculture of the $\mathrm{C}_{3}$ grass Phalaris arundinacea $L$. with 1 or both of the $2 \mathrm{C}_{4}$ grasses present, Agropyron gerardii and Panicum virga tum L. This reversal of dominance is consistent with the general prediction that fires that damage plants during the peak of their growth favor competitors not so affected (Howe 1994a; see Neiland and Curtis 1956). While it is widely understood that spring fires favor $\mathrm{C}_{4}$ grasses (e.g. Hulbert 1986, 1988, Steuter 1987, Anderson 1990, Howe 1994b), the rapid and continuing increases in productivity of $\mathrm{C}_{4}$ grasses, leading to a sharp increase in total productivity in plots burned in May as compared with those burned in August or left unburned, is unexpected after only 2 alternate-year burns. $P$. arundinacea is a quickly establishing and extremely vigorous competitor on wet or wet-mesic sites such as this, often forming virtual monocultures (Galatowitsch and van der Valk 1996, Mergliano and Lesica 1998), as it has in a large experiment planted in 1990 at this site (Howe 1999). Early displacement of this species in May-burn plots is particularly interesting because wet soils often favor $P$. arundinacea. Total productivity, reaching $1,379 \mathrm{~g} \mathrm{~m}^{-2}$ year ${ }^{-1}$ and averaging $781 \pm 212 \mathrm{~g} \mathrm{~m}^{-2}$ year $^{-1}$, may ultimately approach the mean of $>1,100 \mathrm{~g} \mathrm{~m}^{-2}$ year $^{-1}$ on spring-burn treatments in a 1986 planting in which A. gerardii was seeded and established in overwhelming dominance (Howe 1994b, 1995).

August-burn plots present a more complex picture. One might expect that summer burns which occur after a dominant $\mathrm{C}_{3}$ grass completes flowering, seeding, and seasonal growth would strongly favor that dominant through suppression of later-maturing $\mathrm{C}_{4}$ grasses (Howe 1994a).
Alternatively one might expect a general promotion of $\mathrm{C}_{3}$ species, as has occurred in native short-grass prairies (Steuter 1987, Biondini et al. 1989). Here 2 cycles of August fires over 3 years favor $\mathrm{C}_{3}$ grasses (Fig. 2) by breaking the hegemony of $P$. arundinacea in favor of a mixture of this species and 2 other $\mathrm{C}_{3}$ grasses (E. vir ginicus and $P$. pratensis). Despite intrusion of some much more productive $\mathrm{C}_{4}$ experimentals after August burns, overall productivity of August-burn plots may be declining from the $P$. arundinacea monoculture high of $495 \pm 66 \mathrm{~g} \mathrm{~m}^{-2}$ year $^{-1}$ to a 1998 mean of $362 \pm 28 \mathrm{~g} \mathrm{~m}^{-2}$ year $^{-1}\left(\mathrm{t}_{6.8}=\right.$ $1.833, \mathrm{P}=0.1$ ). Mid-summer fires favor $\mathrm{C}_{3}$ grasses more than spring fires, but the net result seems to be a mixture of $\mathrm{C}_{3}$ and $\mathrm{C}_{4}$ grasses instead of the anticipated encouragement of continued dominance of $P$. arundinacea.

Unburned plots are least productive in this experiment. Despite incursions of heavy $\mathrm{C}_{4}$ species and the pre-treatment monoculture of $P$. arundinacea, unburned plots have a low and at present declining productivity of $262 \pm 43 \mathrm{~g} \mathrm{~m}^{-2}$ year $^{-1}$. The statistical picture is not yet definitive because vegetation in unburned plots does not differ dramatically from August-burn plots. However declining productivity, lower numerical if not statistical speciesspecific variables of $\mathrm{C}_{3}$ grasses, and accumulation of four times as much litter in unburned as August-burn plots suggest that these treatments are diverging, if only because deep litter is known to preclude seedling establishment and ultimately eliminate some species (Hulbert 1969, Knapp and Seastedt 1986). The eventual differences between unburned and August-burn plots will depend on whether summer fires continue to favor small and relatively unproductive $\mathrm{C}_{3}$ species, while unburned plots favor established $\mathrm{C}_{3}$ dominance of $P$. arundinacea or eventually allow vigorous competition from larger and much more productive $\mathrm{C}_{4} A$. gerardii and $P$. virgatum.

\section{Implications of summer fires}

Summer fires have important implications for evolutionary history, ecology, and variability of grasslands in central North America. If they consistently favor different properties and species compositions than dormant-season or early spring fires usually prescribed, summer fires may offer important insights into the management and restoration of tallgrass habitats, which are among the "most endangered" ecosystems in North America (Noss et al. 1995).
The vast majority of non-anthropogenic fires in the Northern Great Plains occur in June, July, and August, with rare but sometimes widespread fires occurring when fire is usually prescribed in late fall, winter or spring (Nelson and England 1971, Higgins 1984). Storm patterns suggest that summer lightning fires were once common throughout central North America (Komarek 1968), and macrofossils of flowering individual plants indicate that tallgrass prairies were repeatedly burned during the growing season at least millenia ago (Baker et al. 1996). Emphasis on promotion and study of dominance of $\mathrm{C}_{4}$ grasses by prescribed dormant-season fire may lead us to overlook the quite different attributes of grasslands left unburned or burned by summer lightning fires (Howe 1994a).

Secondly, I infer from Higgins' (1984) observation that $\mathrm{C}_{3}$ grasses are shorter than $\mathrm{C}_{4}$ grasses and that changes in species composition introduced by seasonal fire should influence overall productivity. Such a shift in the $\mathrm{C}_{3} / \mathrm{C}_{4}$ ratio of biomass appears to be underway in this study, where cool-season $\mathrm{C}_{3}$ grasses $E$. virgini cus, $P$. arundinacea $L$. and $P$. pratensis favored by August fires are substantially lighter than $A$. gerardii and $P$. virgatum favored by May fires. Plots burned in May are more than twice as productive as those burned in August or left unburned.

Thirdly, summer fires may encourage subdominants by temporarily suppressing the dominant species at a time when opportunistic species can establish (Howe 1999). Even temporary suppression of dominant vegetation often increases biodiversity as competitively "saturated" communities admit species that can take advantage of space or resources once occupied by dominants (see Huston 1979, Cornell and Lawton 1992). The present study uses too few species for a definitive test of this prediction, but invasion of summer-burn plots by $P$. pratensis and other weeds which had occupied mowed fire lanes offers anecdotal support. In a natural community with native opportunists, one would expect a similar response with native species.

Finally, summer fire intensity is more variable than spring fire intensity. Methods used in this study (burning from the perimeter on windless days) preclude dissection of subtle effects of fire behavior on vegetation (Bidwell et al. 1990, Bidwell and Engle 1992), but differences in variability of intensity and effect were clear. One set of spring burns averaged one fourth of the intensity of summer 
burns, in the second set the opposite was true (Table 1). However, both spring fires and a higher-intensity summer fire removed all vegetation, while the lowintensity summer fires in 1997 left enough green vegetation standing dead to provide shade, a common occurrence in highly variable summer fires (Howe 1995, 1999). For instance, a few days following the 1997 summer fires reported here (Table 1), a series of 24 burns in an experiment in the same field ranged from half to 30 times the average intensity shown here, leaving some plots covered with dead vegetation and others entirely bare (Howe 1999). If subdominant species or other potential dominants were to take advantage of dominants suppressed by summer fires, a wide variety of microhabitats were accessible to them. Given that fire behavior (Bidwell and Engle 1992) as well as vegetative responses are likely to be multivariate, it appears likely that summer fires in heavy green vegetation introduce more variability in physical behavior and effects than spring burns.

\section{Literature Cited}

Anderson, R. C. 1990. The historic role of fire in North American grassland, p. 8-18. In: S. L. Collins and L. L. Wallace (eds.), Fire in North American Tallgrass prairies. Univ. Olka. Press, Norman, Okla.

Baker, R. G., E. A. Bettis, III, D. P. Schwert, D. G. Horton, C. A. Chumbley, L. A. Gonzalez, and M. K. Reagan, M. K. 1996. Holocene paleoenvironments of northeast Iowa. Ecol. Monogr. 66:203-234.

Bidwell, T. G. and D. M. Engle. 1992. Relationship of fire behavior to tallgrass prairie herbage production. J. Range Manage. 45:579-584.

Bidwell, T. G., D. M. Engle, and P. L. Claypool. 1990. Effects of spring headfires and backfires on tallgrass prairie. J. Range Manage. 43:209-212.

Biondini, M., A. A. Steuter, and G. E. Grygiel. 1989. Seasonal fire effects on the diversity patterns, spatial distribution and community strucure of forbs in the Northern Mixed Prairie, USA.Vegetatio 85: 21-31.

Bragg, T. B. 1982. Seasonal variations in fuel and fuel consumption by fires in a bluestem prairie. Ecol. 63:7-11.

Collins, S. L. and L. L Wallace. (eds.). 1990. Fire in North American tall grass prairies.University of Oklahoma Press, Norman, Okla.

Cornell, H. V. and J. Lawton. 1992. Species interactions, local and regional processes, and limits to the richness of ecological communities: a theoretical perspective. J. Anim. Ecol. 61:1-12.

Curtis, J. T. 1959. The vegetation of Wisconsin. Univ. Wis. Press, Madison, Wisc.
Daubenmire, R. 1968. Ecology of fire in grasslands. Advan. Ecol. Res. 5:209-266.

Elias, M. K. 1942. Tertiary prairie grasses and other herbs from the High plains. Geol. Soc. Amer. Spec. Paper 41:1-176.

Galatowitsch, S. M. and A. G. van der Valk. 1996. The vegetation of restored and natural prairie wetlands. Ecol. Applic. 6:102-112.

Higgins, K. F. 1984. Lightning fires in North Dakota grasslands and in pine-savanna lands of South Dakota and Montana. J. Range Manage. 37:100-103.

Howe, H. F. 1994a. Managing species diversity in tallgrass prairie: assumptions and implications. Conserv. Biol.8:691-704.

Howe, H. F. 1994b. Response of early- and late-flowering plants to fire season in experimental prairies. Ecol. Appl. 4:121-133.

Howe, H. F. 1995. Succession and fire season in experimental prairie plantings. Ecol. 76:1917-1925.

Howe, H. F. 1999. Response of Zizia aurea to season mowing and fire in a restored prairie. Amer. Midl. Natur. 141:373-380.

Hulbert, L. C. 1969. Fire and litter effects in undisturbed bluestem prairie in Kansas. Ecol. 50:874-877.

Hulbert, L. C. 1973. Management of Konza prairie to approximate pre-white-man influences, p. 14-17. In: L. C. Hulbert (ed.), Proc. 3rd Midwest Prairie Conf. Kansas State University, Manhattan, Kans.

Hulbert, L. C. 1986. Fire effects on tallgrass prairie, p. 138-142. In: G. K. Clambey and R. K. Pemble (eds), The prairie: past present and future. Proc. 9th North Amer. Prairie Conf. Tri-College University Center for Environ. Studies, Fargo, N.D.

Hulbert, L. C. 1988. The causes of fire effects in tallgrass prairie. Ecol. 69:46-58.

Huston, M. 1979. A general hypothesis of species diversity. Amer. Natur. 113:81-101.

Johnson, E. A. 1992. Fire and vegetation dynamics. Cambridge Univ. Press, Cambridge, U.K.

Knapp, A. K. and T. R. Seastedt. 1986. Detritus accumulation limits productivity of tallgrass prairie. Biosci. 36:662-668.

Komarek, E. V. 1968. Lightning and lightning fires as ecological forces. Tall Timbers Fire Ecol. Conf. 8:169-197.

Leach, M. K. and T. J. Givnish. 1996. Ecological determinants of species loss in remnant prairies. Sci. 273:1555-1558.

McCain, W. E. 1986. Illinois prairie: Past and future. A restoration guide. Illinois Dept. Cons., Springfield, Ill.

Mergliano, M. F. and P. Lesica. 1998. The native status of reed canarygrass (Phalaris arundinacea L.) In the inland Northwest, USA. Natur. Areas J. 18:223-230.

Neiland, B. M. and J. T. Curtis. 1956. Differential responses to clipping of six prairie plants in Wisconsin. Ecol. 37:355-365.

Nelson, J. G. and R. E. England. 1971. Some comments on the causes and effects of fire in the Northern grasslands area of Canada and the nearby United States, Ca. 1750-1900. Can. Geog.15:295-305.
Noss, R. F., E. T. LaRoe, III, and J. M. Scott. 1995. Endangered ecosystems of the United States: A preliminary assessment of loss and degradation. Nat. Biol. Serv., Dep.Interior. U. S. Gov. Printing Office, Wash., D.C.

Risser, P. G., E. C. Birney, H. D. Blocker, S.W. May, W. J. Parton, and J. A. Wiens. 1981. The true prairie ecosystem. Hutchinson Ross Publ., Stroudsburg, Penn.

Rock, H. 1981. Prairie propagation handbook. 6th Ed., Wehr Nature Center, Milwaukee, Wis.

Saur, C. O. 1950. Grassland climax, fire, and man. J. Range Manage. 3:59-69.

Steuter, A. A. 1987. $C_{3} / C_{4}$ production shift on seasonal burns-Northern Mixed Prairie. J. Range Manage. 40:27-31.

Towne, G. and C. Owensby. 1984. Long-term effects of annual burning at different dates in ungrazed Kansas tallgrass prairie. J. Range Manage 37:392-397.

Wilkinson, L. 1993. Systat: the system for statistics. Systat Inc., Evanston, Ill. 